AJChE 2017, Vol. 17, No. 2, 51 - 59

\title{
Assessment of Aqueous Lithium-based Salt Solutions as Working Fluid for Ahsorption Chillers using Aspen Plus ${ }^{\circledR \dagger}$
}

\author{
Adonis P. Adornado *,1 \\ Allan N. Soriano ${ }^{1}$ \\ Vergel C. Bungay ${ }^{2}$ \\ 1 School of Chemical, Biological, and Materials Engineering and Sciences, Mapúa University, \\ Intramuros, Manila 1002, Philippines \\ ${ }^{2}$ Department of Chemical Engineering, De La Salle University, Taft Ave., Manila 1004, Philippines \\ *e-mail: apadornado@mapua.edu.ph
}

Absorption chillers are a viable option for providing waste heat-powered cooling or refrigeration, thereby improving overall energy efficiency-less primary energy input, lower emissions, and cost savings. This study focuses on the assessment of aqueous lithium-based salt solutions as working fluid for absorption chiller in exploring the possibility of developing new mixtures for absorption chillers to improve the performance of the absorption refrigeration systems (ARSs). In this paper, the coefficient of performance (COP) of a single-effect absorption chiller using aqueous lithium-based salt solutions ( $\mathrm{LiF}-\mathrm{H}_{2} \mathrm{O}, \mathrm{LiCl}-\mathrm{H}_{2} \mathrm{O}, \mathrm{LiBr}-\mathrm{H}_{2} \mathrm{O}$, and $\mathrm{Lil}-\mathrm{H}_{2} \mathrm{O}$ ) as working fluid was assessed using Aspen Plus ${ }^{\circledR}$. The simulation results obtained showed that the mass and energy were well balanced for all systems. Furthermore, a direct proportionality relationship between COP of absorption chillers and the van't Hoff factor, $i$ of dissociated aqueous salt solutions was observed. The highest COP value is 0.8930 for $\mathrm{Lil}-\mathrm{H}_{2} \mathrm{O}$ among others.

Keywords: absorption chiller, lithium-based salt, refrigerant-absorbent pairs, water, coefficient of performance, Aspen Plus ${ }^{\circledR}$

\section{INTRODUCTION}

In recent years, there have been numerous researches devoted to absorption refrigeration systems (ARSs) because these systems harness and utilize inexpensive energy sources like waste heat from power production processes for airconditioning or refrigeration, in comparison to mechanical vapor compression refrigerators that require high grade energy for its operation. Here, waste heat is defined as heat in processes that would otherwise be rejected to ambient.

An absorption chiller is a key technology to provide this functionality of transforming waste heat into cooling or refrigeration. Although, ARSs have been known for more than 150 years, it has been limitedly used due to its relatively poor efficiency compared to vapor compressions cycles. However, absorption chillers continue to be more viable in some applications since the temperature

This article has been presented or read during the $23^{\text {rd }}$ Regional Symposium on Chemical Engineering (RSCE 2016) held last 27-28 October 2016 in Vung Tau City, Vietnam. 
52 Assessment of Aqueous Lithium-based Salt Solutions as Working Fluid for Absorption Chillers using Aspen Plus ${ }^{\circledR}$

requirements for the cycle fell into the low to moderate temperature $\left(<100^{\circ} \mathrm{C}\right)$ heat range to provide cooling. In that context, the performance of an absorption chiller cannot be compared to other cooling cycles since the input energy for an absorption chiller can be essentially free. Thus, in processes where low temperature waste heat is available and cooling is desired, it often makes sense to put up an absorption chiller to increase the overall energy efficiency of the process (Hufford, 1992; Moné et al., 2001; Florides et al., 2002; Maidment \& Tozer, 2002; Sumathy et al., 2002).

ARSs provide a number of benefits, with the absorption chiller utilizing waste heat; the primary benefit is a reduction in the energy demand of the process. Increased energy efficiency has a number of additional benefits, including reducing primary energy input, reducing carbon dioxide $\left(\mathrm{CO}_{2}\right)$ and other emissions, and reducing operating and utility costs. Thus, ARSs can be considered as a waste heat utilization measure. Other advantages also include reduced environmental impact because no ozone depleting substances such as chlorofluorocarbons (CFCs) or hydrochlorofluorocarbons refrigerants are needed, and they produce less noise and vibration. The ozone layer, CFC-free conventional compression systems are currently being developed (Gebreslassie et al., 2009; Sieres et al., 2009), mainly with hydrofluorocarbons (HFCs). Nevertheless, these new refrigerants raise man-induced greenhouse gas levels and increase $\mathrm{CO}_{2}$ emission and therefore might be banned in the next decades (Gebreslassie et al., 2009). In addition, absorption chiller modeled in Aspen Plus $^{\circledR}$ would have a number of advantages being one of the most sophisticated process simulation software available today. It is a very useful, easy, and flexible engineering software which allows for steady-state process modeling with optimization capabilities, able to solve the most challenging problems (Aspen Plus ${ }^{\circledR}$, 2006; Tremblay et al., 2010), and was also continually utilized in several researchers conducted by Leron et al. (2014), Soriano et al. (2015), Nieva et al. (2016), and Adornado et al. (2017), to mention a few.

Absorption chillers use a refrigerantabsorbent pair as a working fluid. Even though the prevalent working pairs such as water/lithium bromide ( $\mathrm{LiBr}$ ) and water/ammonia $\left(\mathrm{NH}_{3}\right)$ meet the existing requirements of common applications quite well, as these applications advance, further requirements have to be discussed and require a reanimation of research activities regarding new working pairs to overcome the drawbacks of the prevalent working pairs. Only few research groups proposed and investigated new refrigeration-absorption working pairs. In fact, there is limited literature on other refrigerant-absorbent pairs and its mixtures for absorption chillers, mainly due to the unavailability or inadequate number of pilot facilities, and mostly restricted by the incurred operating and utility costs of exploring each working pair one by one. A suitable working fluid is one of the most important factors affecting the performance of the ARSs.

Hence, this study focuses on the assessment of coefficient of performance (COP) of a single-effect absorption chiller 
using aqueous lithium-based salt solutions ( $\mathrm{LiF}-\mathrm{H}_{2} \mathrm{O}$, LiCl- $\mathrm{H}_{2} \mathrm{O}$, LiBr- $\mathrm{H}_{2} \mathrm{O}$, and $\mathrm{Lil}-\mathrm{H}_{2} \mathrm{O}$ ) as working fluid using Aspen Plus ${ }^{\circledR}$.

\section{METHODOLOGY}

\section{Selection of Refrigerant-Absorbent Pairs}

The success of absorption process depends on the choice of an appropriate pair of refrigerant and absorbent. In general, selection of the working fluids for the absorption cycles are based on (a) chemical and physical properties of the fluids, and (b) acceptability range for certain thermophysical and thermodynamic properties of the fluids.

Some of the desirable characteristics of a refrigerant-absorbent mixture are: (i) high degree of negative deviation from Raoult's law, (ii) low viscosity of the solution under the desired operating conditions; this reduces the pump work, (iii) freezing points of the liquid should be below the lowest temperature in the cycle, (iv) good chemical thermal stability, (v) non-corrosive, nontoxic, and non-flammable, (vi) high equilibrium and solubility of the refrigerant in the absorbent, and (vii) a large difference in boiling points of the absorbent and the refrigerant.

The refrigerant should also possess the following characteristics: (i) high enthalpy of vaporization for better coefficients of performance, (ii) high critical temperature and pressure in order to have large range of isothermal energy transfer during condensation, (iii) low specific heat so that sub-cooling of liquid increases, (iv) low molecular weight, and (v) high affinity for the absorbent at low temperatures, while less at high temperatures. In this context, the following aqueous lithium-based salt solutions are considered: (a) $\mathrm{LiF}-\mathrm{H}_{2} \mathrm{O}$, (b) $\mathrm{LiCl}-\mathrm{H}_{2} \mathrm{O}$, (c) $\mathrm{LiBr}-\mathrm{H}_{2} \mathrm{O}$, and (d) $\mathrm{Lil}-\mathrm{H}_{2} \mathrm{O}$.

\section{Adaptation of Single-Effect Cycle Model}

In the work of Somers et al. (2011), a validated modeling methodology for single-effect absorption cycles implemented in Aspen Plus ${ }^{\circledR}$ was presented with $3 \%$ discrepancy for the main singleeffect absorption cycles parameters verified with reference data that indicated that the model provide sufficiently accurate results. Thus, the same cycle model shown in Figure 1 was implemented in this study.

\section{Replication of the Adapted Single-Effect Cycle Model}

In order to validate the correctness and accuracy of the reproduced single-effect cycle model in Aspen Plus $^{\circledR}$ v8.6, a preliminary simulation run was conducted wherein the results are compared with the work of Somers et al. (2011) and the discrepancy on the values of the obtained cycle parameters was taken into account as shown in Table 1.

\section{RESULTS AND DISCUSSION}

The verified reproduced single-effect cycle model in Aspen Plus ${ }^{\circledR}$ v8.6 was used to simulate the following aqueous lithiumbased salt solutions: (a) $\mathrm{LiF}-\mathrm{H}_{2} \mathrm{O}$, (b) $\mathrm{LiCl}-$ $\mathrm{H}_{2} \mathrm{O}$, (c) $\mathrm{LiBr}-\mathrm{H}_{2} \mathrm{O}$, and (d) $\mathrm{Lil}-\mathrm{H}_{2} \mathrm{O}$, where the results were compared to assess the performance of each refrigerant-absorbent pairs as working fluid for absorption chillers. Take note that the same assumptions were made in simulating all of 


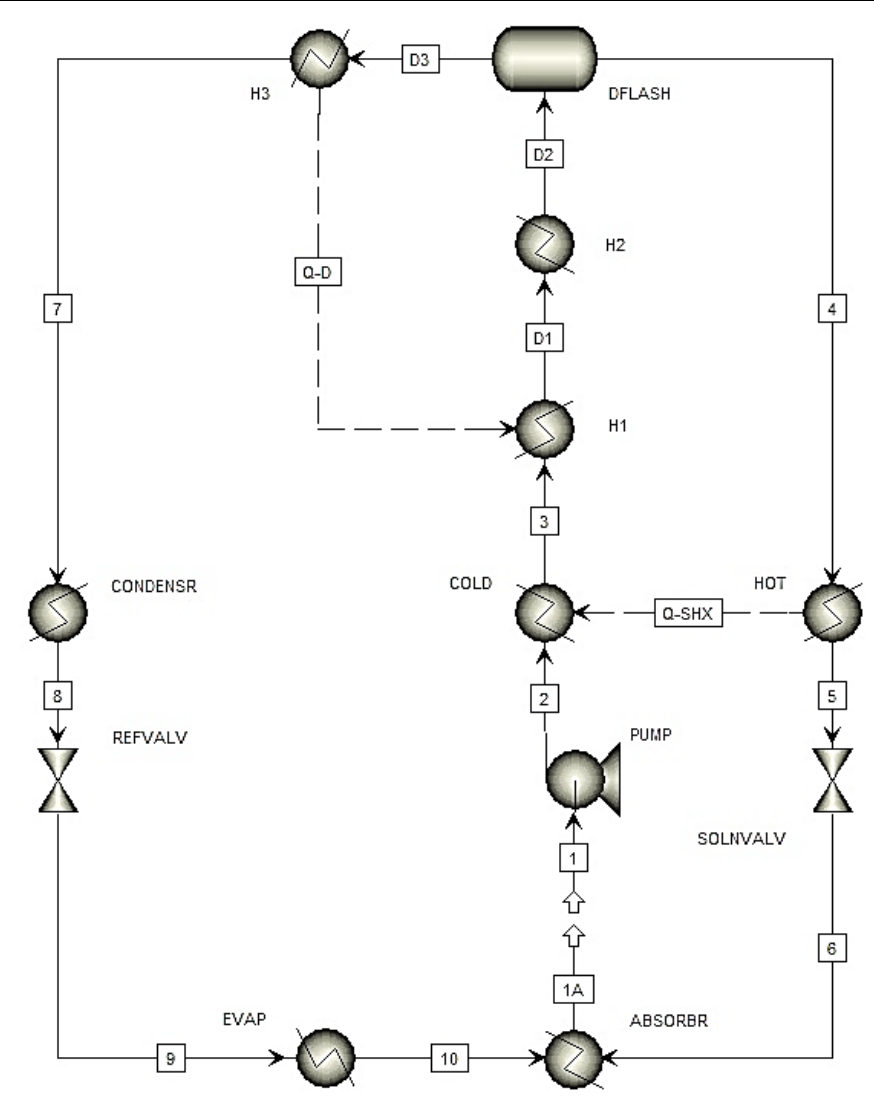

Fig. 1: Single-effect cycle model implemented in Aspen Plus ${ }^{\circledR}$ v8.6.

Table 1. Single-effect cycle verification

\begin{tabular}{lccc}
\hline Parameter & $\begin{array}{c}\text { Somers et al. } \\
\text { (2012) }\end{array}$ & This work & Discrepancy (\%) \\
\hline$P$ low $(\mathrm{kPa})$ & 0.6715 & 0.6715 & 0.00 \\
$P$ high $(\mathrm{kPa})$ & 7.4606 & 7.4606 & 0.00 \\
$\begin{array}{l}\text { Conc., } \mathrm{LiBr} \\
\quad \text { strong solution (\%) }\end{array}$ & 57.400 & 57.400 & 0.00 \\
Conc., LiBr & & & \\
$\quad$ weak solution (\%) & 62.570 & 62.570 & 0.00 \\
$Q$ absorber (kW) & 13.923 & 13.955 & 0.20 \\
$Q$ condenser (kW) & 11.432 & 11.386 & 0.40 \\
$Q$ desorber $(\mathrm{kW})$ & 14.592 & 14.621 & 0.20 \\
$Q$ evaporator $(\mathrm{kW})$ & 10.772 & 10.772 & 0.00 \\
COP $(-)$ & 0.7380 & 0.7370 & 0.10 \\
\hline
\end{tabular}

the systems in the model to allow for a meaningful comparison.

\section{Mass Balance and Energy Conservation Verification}

To perform a mass balance verification for the single-effect model, a "break" in the cycle was included in stream 1 , between the absorber exit and the pump as illustrated in Figure 1. A well-formulated model will conserve mass throughout the cycle, thus resulting in identical overall and component mass flow rates on either side of the break. In the cycle, the stream leaving the absorber was termed " $1 \mathrm{~A}$ " and the stream entering the pump was termed "1". 
Table 2 shows the results of this verification for the single-effect models, and demonstrates the accuracy of the models.

Table 2. Single-effect cycle mass balance verification

\begin{tabular}{lcc}
\hline $\begin{array}{l}\text { Mass Flow } \\
\text { Rate } \mathbf{( k g / s )}\end{array}$ & Stream 1 & Stream 1A \\
\hline Total & 1.000 & 1.000 \\
Water & 0.426 & 0.426 \\
LiF & 0.574 & 0.574 \\
$\mathrm{LiCl}$ & 0.574 & 0.574 \\
$\mathrm{LiBr}$ & 0.574 & 0.574 \\
$\mathrm{Lil}$ & 0.574 & 0.574 \\
\hline
\end{tabular}

Additionally, an energy conservation check was performed to verify that the energy into the cycle was equal to that leaving it. This verification confirms that the net amount of energy into and out of the cycle is zero. Internal energy transfer is not considered in this verification. Thus, Eq. (1) must be satisfied for each cycle.

$$
E_{\text {in }}+E_{\text {out }}=0
$$

This Eq. (1) is applied to the cycle design for a given design point. For the singleeffect cycle, there are five components that contribute to this, shown in Eq. (2). The condenser and absorber reject energy out of the cycle, while the evaporator, desorber, and pump add energy to the cycle.

$$
\begin{aligned}
& \left|Q_{\text {condenser }}+Q_{\text {absorber }}\right|-\mid Q_{\text {evaporator }} \\
& +Q_{\text {desorber }}+W_{\text {pump }} \mid=0
\end{aligned}
$$

The results obtained from Aspen Plus ${ }^{\circledR}$ model for Eqs. (1) and (2) show that the energy was well balanced for all systems.

\section{Single-Effect Cycles}

The model verification performed for the single-effect cycle for selected working fluids are summarized below. Table $\mathbf{3}$ shows the cycle parameter results for LiF$\mathrm{H}_{2} \mathrm{O}$, $\mathrm{Lil}-\mathrm{H}_{2} \mathrm{O}$, $\mathrm{LiCl}-\mathrm{H}_{2} \mathrm{O}$, and $\mathrm{LiBr}-\mathrm{H}_{2} \mathrm{O}$. Note that the evaporator heat duty discrepancy is not predicted as its duty was used as an input to the model. The results showed that among the four working fluids being assessed, Lil- $\mathrm{H}_{2} \mathrm{O}$ has the highest coefficient of performance (COP) value of 0.8930, followed by $\mathrm{Lil}-\mathrm{H}_{2} \mathrm{O}, \mathrm{LiCl}-\mathrm{H}_{2} \mathrm{O}$, and $\mathrm{LiBr}-\mathrm{H}_{2} \mathrm{O}$ with COP values of $0.8838,0.7956$, and 0.7382 , respectively. This could be attributed to the measure of the effect of a

Table 3. Single-effect cycle parameter results

\begin{tabular}{lcccc}
\hline \multicolumn{1}{c}{ Parameter } & LiF- $\mathbf{H}_{2} \mathbf{O}$ & $\mathbf{L i C l}-\mathbf{H}_{2} \mathbf{O}$ & LiBr- $\mathbf{H}_{2} \mathbf{O}$ & Lil- $\mathbf{H}_{2} \mathbf{O}$ \\
\hline$P$ low (kPa) & 0.6715 & 0.6715 & 0.6715 & 0.6715 \\
$P$ high (kPa) & 7.4606 & 7.4606 & 7.4606 & 7.4606 \\
$\begin{array}{c}\text { Conc., (\%) } \\
\text { strong sol'n }\end{array}$ & 57.400 & 57.400 & 57.400 & 57.400 \\
$\begin{array}{c}\text { Conc., (\%) } \\
\text { weak sol'n }\end{array}$ & 78.401 & 68.076 & 62.568 & 87.213 \\
$Q$ abs. (kW) & 11.439 & 12.849 & 13.923 & 11.398 \\
$Q$ cond. (kW) & 11.438 & 11.438 & 11.432 & 11.438 \\
$Q$ des. (kW) & 12.188 & 13.540 & 14.592 & 12.062 \\
$Q$ evap. (kW) & 10.772 & 10.772 & 10.772 & 10.772 \\
COP (-) & 0.8838 & 0.7956 & 0.7382 & 0.8930 \\
\hline
\end{tabular}


solute upon colligative properties such as relative lowering in vapor pressure, elevation of boiling point, and freezing point depression known as the van't Hoff factor, $i$.

The amount or fraction of original solute molecules that have dissociated into ions or radicals per mole (degree of dissociation), usually represented by the Greek symbol $\alpha$ must also be considered. A simple relationship between this parameter and the van't Hoff factor, $i$ is shown in Eq. (3). If the solute substance dissociates into $n$ ions, then

$$
i=1+\alpha(n-1)
$$

Table 4. Relationship of COP and van't Hoff factor, $i$ for aqueous salt solutions

\begin{tabular}{lcc}
\hline $\begin{array}{c}\text { Working } \\
\text { Fluid }\end{array}$ & $\begin{array}{c}\text { Coefficient } \\
\text { of } \\
\text { Performance } \\
\text { (COP) }\end{array}$ & $\begin{array}{c}\text { van't } \\
\text { Hoff } \\
\text { factor, } \boldsymbol{i}\end{array}$ \\
\hline $\mathrm{LiF}-\mathrm{H}_{2} \mathrm{O}$ & 0.8838 & 1.7840 \\
$\mathrm{LiCl}-\mathrm{H}_{2} \mathrm{O}$ & 0.7956 & 1.6808 \\
$\mathrm{LiBr}-\mathrm{H}_{2} \mathrm{O}$ & 0.7382 & 1.6257 \\
$\mathrm{Lil}-\mathrm{H}_{2} \mathrm{O}$ & 0.8930 & 1.8721 \\
\hline
\end{tabular}

An increase in the COP of absorption chillers using aqueous lithium-based salt solutions as working fluid was observed with an increase in the value of van't Hoff factor, $i$ as shown in Table 4.

\section{State Point Results}

A typical set of state points generated by Aspen Plus ${ }^{\circledR}$ for single-effect cycles for each working fluid is given in Tables $5 \mathbf{a}$ to $\mathbf{5 d}$. The numbered streams correspond to various state points of interest shown in Figure 1. For ease of comparison, the mass flow rate was normalized to be $1 \mathrm{~kg} / \mathrm{s}$ for all models.

\section{CONCLUSION}

This paper assessed the suitability of aqueous lithium salt solutions $\left(\mathrm{LiF}-\mathrm{H}_{2} \mathrm{O}\right.$ $\mathrm{LiCl}-\mathrm{H}_{2} \mathrm{O}$, $\mathrm{LiBr}-\mathrm{H}_{2} \mathrm{O}$, and $\mathrm{Lil}-\mathrm{H}_{2} \mathrm{O}$ ) as working fluid for absorption chiller to improve the performance of the absorption refrigeration systems (ARSs). Indeed, the success of absorption refrigeration process depends on the choice of an appropriate pair of refrigerant and absorbent. The validated modeling methodology in the work of Somers et al. (2011) for singleeffect absorption cycles implemented in

Table 5a. Single-effect cycle state point results for $\mathrm{LiF}-\mathrm{H}_{2} \mathrm{O}$

\begin{tabular}{cccccc}
\hline $\begin{array}{c}\text { State } \\
\text { Point }\end{array}$ & $\begin{array}{c}\text { Temperature } \\
\left({ }^{\circ} \mathbf{C}\right)\end{array}$ & $\begin{array}{c}\text { Pressure } \\
(\mathbf{k P a})\end{array}$ & $\begin{array}{c}\mathbf{X}_{\text {vapor }} \\
(-\mathbf{)}\end{array}$ & $\begin{array}{c}\text { MFR } \\
(\mathbf{k g} / \mathbf{s})\end{array}$ & $\begin{array}{c}\text { LiF Conc. } \\
(\%)\end{array}$ \\
\hline 1 & 21.7 & 0.672 & 0.0000 & 1.000 & 57.4 \\
2 & 21.7 & 7.461 & 0.0000 & 1.000 & 57.4 \\
3 & 45.4 & 7.461 & 0.0000 & 1.000 & 57.4 \\
4 & 89.9 & 7.461 & 0.0000 & 0.732 & 78.4 \\
5 & 46.3 & 7.461 & 0.0000 & 0.732 & 78.4 \\
6 & 37.4 & 0.672 & 0.0013 & 0.732 & 78.4 \\
7 & 78.4 & 7.461 & 1.0000 & 0.268 & 0.0 \\
8 & 40.1 & 7.461 & 0.0000 & 0.268 & 0.0 \\
9 & 1.2 & 0.672 & 0.0652 & 0.268 & 0.0 \\
10 & 1.2 & 0.672 & 1.0000 & 0.268 & 0.0 \\
\hline
\end{tabular}


Table 5b. Single-effect cycle state point results for $\mathrm{LiCl}-\mathrm{H}_{2} \mathrm{O}$

\begin{tabular}{cccccc}
\hline $\begin{array}{c}\text { State } \\
\text { Point }\end{array}$ & $\begin{array}{c}\text { Temperature } \\
\left({ }^{\circ} \mathbf{C}\right)\end{array}$ & $\begin{array}{c}\text { Pressure } \\
(\mathbf{k P a})\end{array}$ & $\begin{array}{c}\text { Xvapor } \\
\mathbf{( - )}\end{array}$ & $\begin{array}{c}\text { MFR } \\
(\mathbf{k g} / \mathbf{s})\end{array}$ & $\begin{array}{c}\text { LiCl Conc. } \\
(\%)\end{array}$ \\
\hline 1 & 30.3 & 0.672 & 0.0000 & 1.000 & 57.4 \\
2 & 30.3 & 7.461 & 0.0000 & 1.000 & 57.4 \\
3 & 60.3 & 7.461 & 0.0000 & 1.000 & 57.4 \\
4 & 89.9 & 7.461 & 0.0000 & 0.843 & 68.1 \\
5 & 51.8 & 7.461 & 0.0000 & 0.843 & 68.1 \\
6 & 40.7 & 0.672 & 0.0112 & 0.843 & 68.1 \\
7 & 78.4 & 7.461 & 1.0000 & 0.157 & 0.0 \\
8 & 40.1 & 7.461 & 0.0000 & 0.157 & 0.0 \\
9 & 1.2 & 0.672 & 0.0652 & 0.157 & 0.0 \\
10 & 1.2 & 0.672 & 1.0000 & 0.157 & 0.0 \\
\hline
\end{tabular}

Table 5c. Single-effect cycle state point results for $\mathrm{LiBr}-\mathrm{H}_{2} \mathrm{O}$

\begin{tabular}{cccccc}
\hline $\begin{array}{c}\text { State } \\
\text { Point }\end{array}$ & $\begin{array}{c}\text { Temperature } \\
\left({ }^{\circ} \mathbf{C}\right)\end{array}$ & $\begin{array}{c}\text { Pressure } \\
(\mathbf{k P a})\end{array}$ & $\begin{array}{c}\text { Xvapor } \\
(-\mathbf{)}\end{array}$ & $\begin{array}{c}\text { MFR } \\
(\mathbf{k g} / \mathbf{s})\end{array}$ & $\begin{array}{c}\text { LiBr Conc. } \\
(\%)\end{array}$ \\
\hline 1 & 32.7 & 0.672 & 0.0000 & 1.000 & 57.4 \\
2 & 32.7 & 7.461 & 0.0000 & 1.000 & 57.4 \\
3 & 63.8 & 7.461 & 0.0000 & 1.000 & 57.4 \\
4 & 89.9 & 7.461 & 0.0000 & 0.918 & 62.6 \\
5 & 53.3 & 7.461 & 0.0000 & 0.918 & 62.6 \\
6 & 43.1 & 0.672 & 0.0112 & 0.918 & 62.6 \\
7 & 78.4 & 7.461 & 1.0000 & 0.083 & 0.0 \\
8 & 40.2 & 7.461 & 0.0000 & 0.083 & 0.0 \\
9 & 1.3 & 0.672 & 0.0700 & 0.083 & 0.0 \\
10 & 1.3 & 0.672 & 1.0000 & 0.083 & 0.0 \\
\hline
\end{tabular}

Table 5d. Single-effect cycle state point results for $\mathrm{Lil}^{-\mathrm{H}_{2} \mathrm{O}}$

\begin{tabular}{cccccc}
\hline $\begin{array}{c}\text { State } \\
\text { Point }\end{array}$ & $\begin{array}{c}\text { Temperature } \\
\left({ }^{\circ} \mathbf{C}\right)\end{array}$ & $\begin{array}{c}\text { Pressure } \\
(\mathbf{k P a})\end{array}$ & $\begin{array}{c}\mathbf{X}_{\text {vapor }} \\
\mathbf{( - )}\end{array}$ & $\begin{array}{c}\text { MFR } \\
(\mathbf{k g} / \mathbf{s})\end{array}$ & $\begin{array}{c}\text { Lil Conc. } \\
(\%)\end{array}$ \\
\hline 1 & 10.6 & 0.672 & 0.0000 & 1.000 & 57.4 \\
2 & 10.6 & 7.461 & 0.0000 & 1.000 & 57.4 \\
3 & 14.1 & 7.461 & 0.0000 & 1.000 & 57.4 \\
4 & 89.9 & 7.461 & 0.0000 & 0.658 & 87.2 \\
5 & 39.2 & 7.461 & 0.0000 & 0.658 & 87.2 \\
6 & 37.2 & 0.672 & 0.0005 & 0.658 & 87.2 \\
7 & 78.4 & 7.461 & 1.0000 & 0.342 & 0.0 \\
8 & 40.1 & 7.461 & 0.0000 & 0.342 & 0.0 \\
9 & 1.2 & 0.672 & 0.0652 & 0.342 & 0.0 \\
10 & 1.2 & 0.672 & 1.0000 & 0.342 & 0.0 \\
\hline
\end{tabular}

Aspen Plus ${ }^{\circledR}$ was adapted in this study. The reproduced single-effect cycle model in Aspen Plus ${ }^{\circledR}$ v8.6 was verified for its correctness and accuracy by running a preliminary simulation known to have good agreement with the prior work. The results obtained from Aspen Plus ${ }^{\circledR}$ model for all working equations show that the mass and energy was well balanced for all systems. In addition, it was observed that an increase 
in the coefficient of performance (COP) of absorption chillers using aqueous salt solutions as working fluid was observed with an increase in the value of van't Hoff factor, $i$ with $\mathrm{Lil}-\mathrm{H}_{2} \mathrm{O}$ system having the highest COP of value 0.8930. The absorption cycle model presented is generically applicable to a wide range of applications allowing investigation into the benefits of using absorption chillers for waste heat utilization and explores the possibility of developing new mixtures for absorption chillers to improve the performance of ARSs.

\section{ACKNOWLEDGEMENT}

This research was supported by the Department of Science and TechnologyEngineering Research and Development for Technology (DOST-ERDT) thru a scholarship/research grant coordinated by the Mapúa University-School of Graduate Studies (GS).

\section{REFERENCES}

1. Adornado, A. P., Soriano, A. N., Orfiana, O. N., Pangon, M. B. J., \& Nieva, A. D. (2017). "Simulated Biosorption of Cd (II) and $\mathrm{Cu}$ (II) in Single and Binary Metal Systems by Water Hyacinth (Eichhornia crassipes) using Aspen Adsorption". AJChE, 2, 21-43.

2. Aspen Plus ${ }^{\circledR}$, Version 2006, Aspen Technology Inc., 200 Wheeler Road Burlington, MA, USA.

3. Florides, G., S. Kalogirou, S. Tassou, and L. Wrobel (2002). "Modelling and simulation of an absorption solar cooling system for Cyprus". Solar
Energy, 72, 43-51.

4. Gebreslassie, B., G. Guillén-Gosálbez, L. Jiménez, and D. Boer (2009). "Design of environmentally conscious absorption cooling systems via multi-objective optimization and life cycle assessment". Appl. Energy, 86, 1712-1722.

5. Hufford, P. (1992). "Absorption chillers improve cogeneration energy efficiency". ASHRAE Journal, 34, 46-53.

6. Leron, G. M., A. P. Adornado, D. G. Zalvidea, L. P. Gutierrez, S. W. B. Suarez, A. N. Soriano, and M.-H. Li (2014). Selection of single and blended aqueous alkanolamine for postcombustion carbon dioxide capture using rate-based non-equilibrium process simulation. PIChE Journal, Vol. 15 (1).

7. Maidment, G. and R. Tozer (2002). "Combined cooling heating and power in supermarkets". Appl. Therm. Eng., 22, 653-665.

8. Moné, C., D. Chau, and P. Phelan (2001). "Economic feasibility of combined heat and power and absorption refrigeration with commercially available gas turbines". Energ. Convers. Manage., 42, 1559-1573.

9. Nieva, A. D., F. C. De Vera, A. P. Adornado, B. P. Gallarte, and B. T. Doma Jr. (2016). "Simulation of biosorption of lead and copper with Pinus insularis using Aspen Adsorption ${ }^{\circledR}$. PIChE Journal, Vol. 16 (1).

10. Sieres, J., J. Fernandez-Seara, and F. Uhia (2009). "Experimental characterization of the rectification process in ammonia-water absorption systems with a large-specific-area corrugated sheet structured packing". 
Int. J. Refrig., 32, 1230-1240.

11. Somers, C., A. Mortazavi, Y. Hwang, R. Radermacher, P. Rodgers, and S. AlHashimi (2011). "Modeling water/lithium bromide absorption chillers in ASPEN Plus". Appl. Energy, 88, 4197-4205.

12. Soriano, A. N., A. P. Adornado, A. A. Pajinag, D. J. F. Acosta, N. M. Averion, G. M. Leron, and V. C. Bungay (2015). "Multicriterial analysis of simulated process of post-combustion capture of pure $\mathrm{H}_{2} \mathrm{~S}$ and mixtures of $\mathrm{H}_{2} \mathrm{~S}$ and $\mathrm{CO}_{2}$ using single and blended aqueous alkanolamines". AJChE, 1, 72-92.
13. Sumathy, K., Z. Huang, and Z. Li (2002). "Solar absorption cooling with low grade heat source-a strategy of development in South China". Solar Energy, 72, 155-165.

14. Tremblay, D., S. Watanasiri, Y. Song, and C.-C. Chen (2010). "Benefits of the new electrolyte models in Aspen Plus ${ }^{\circledR}$ version 7.2". Best in Class Electrolyte Thermodynamics. Aspen Technology Incorporated, Ten Canal, Cambridge, U. S. A. 